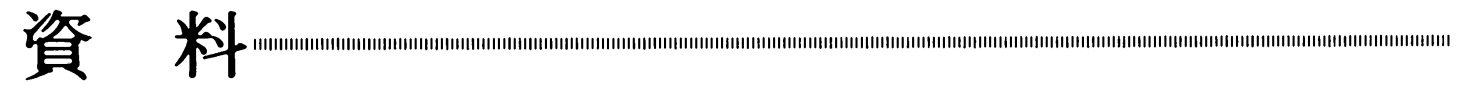

\section{FA 用ゴム製アクチュエータと把持装置(2) 一ニューマチックハンドの開発}

渡辺功*

\section{1.はじめに}

最近の産業用口ボットは，高速・高精度なもの から柔軟性を有するものまで幅広く開発され、工 場の各現場で目さましい活躍をしている。ワーク と直接接触するハントの部分も技術革新が進んで いるか，多品種小量生産を必要とする生産現場て は，更にワークに合わせた機能をもつ柔軟性のあ るハントが要求されている。

現在広く使用されているハントとしては、イカ ニカルなチ十ックや真空・ットがある。しかし、 これらのハントはワークが多様化するなかで，賃 つきやすい，変形しやすい，一定の形状をしてい， ない、クリーン度が要求されるなど取り扱いか困 嚾なワーク，例之はブラスチックチューフ，力ラ ス基，複写機の感光トラムなとは苦手としてい る.したがって、これらのワークに損傷を与える ことなく確実に把持できるハントの出現が待たれ ていた。

当社ではこの期待に応えるため，コム制人工第 を用いた産業用口ボット，乗用車用空気はねンス テムなどの開発で蓄積された技術を応用して，従 来技術では自動化が困嚾と考之られていた現場に も解決の系口を与えるニューマチックハントを開 発した。

\section{2. ニューマチックハンドの概要}

このニューマチックハントは特殊配合コムチュ 一フの内部に空気か注入されるとコムチューフか 膨らみ、ワークをンフトに，しかもしっかりホー ルトする新方式であり，内面保持タイブをェア ピッカー(AIR PICKER)，外面保持タイブをエ フ・クリッハー-(AIR GRIPPER) と呼ふ。. 図1, (a) 造

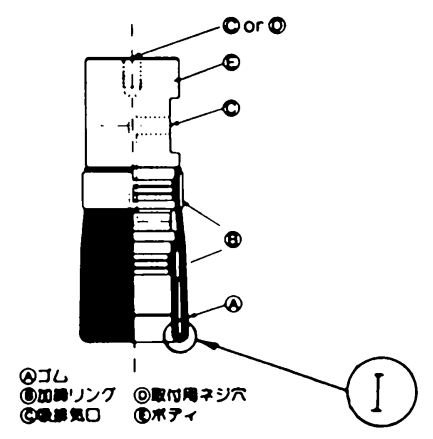

(b) 预作媄明图

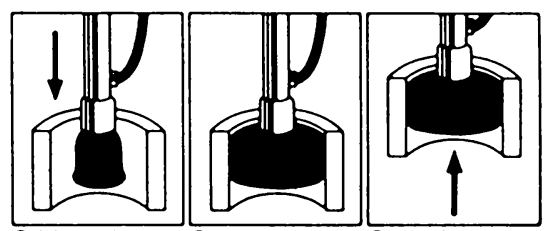

(1)

凶1エア・ビ,カーの浩と作説明区

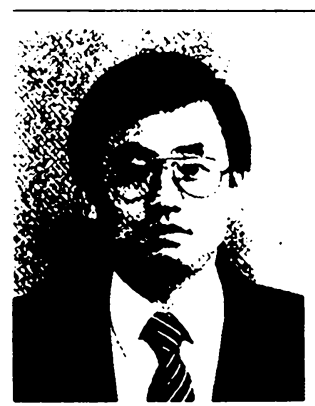

・侏式会社プリチストン( 187 東京都小平市小川東町 3-1-1) 研究開発第 2 本部 研究第 8 グルブ。昭和 54 年, 東京大学工学部産莱 機满工学科信士課程卒莱。 同年、ブリチストンタイヤ (現(現)フリチストン)入 社.

〈整味〉テニス，水冰，卜 ライフ 
(a) 錐造

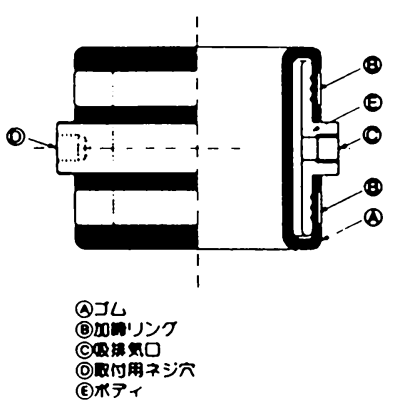

(b) 功作説明図

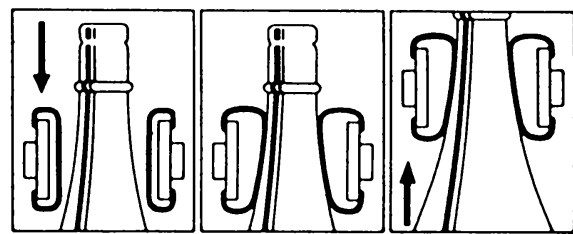

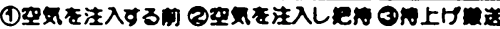

困2エア・グリッハ・ーの槽造と動作説明园

図 2 にこれらの構造及び動作説明㘠を示す。

\section{1 造}

エア・ピッカーは、ゴムチューブの両端をボデ 、に加締めて固定しているコムチューブは(1)の 部分が折り返されている。ボディには吸排気口が あり、レギュレータで圧力調整された圧縮空気が 注入されるとコムチューブが外側に膨張する。 こ の種類のハンドは，径方向に大きく膨らませるこ とがポイントであることはもちろんのこと，軽薄 短小のワークが最近增加していることもあって, コムチューブの下端がなるべく大きく膨らむこと が要求されている。このエア・ビッカーは，コム チューブの(1)部分が折り返されていることが特 徵であり，図 3 に示すよ5に従来構造に比べてワ 一クが固いてある面に近い部分が大きく膨らむの で，薄いワークであっても充分把持できる。

エア・グリッハーは，エア・ピッカー同様にコ ムチューブの両端をボデ、に加締めて固定してい る. 圧力調整された圧縮空気が吸排気口から注入 されるとゴムチューブは内側に膨張する。

エア・ピッカー、エア・グリッハーのコムムュ ーブは総ゴムタイプとコード入りコムタイブがあ る、総ゴムタイブは比較的低い珐力で膨らむの

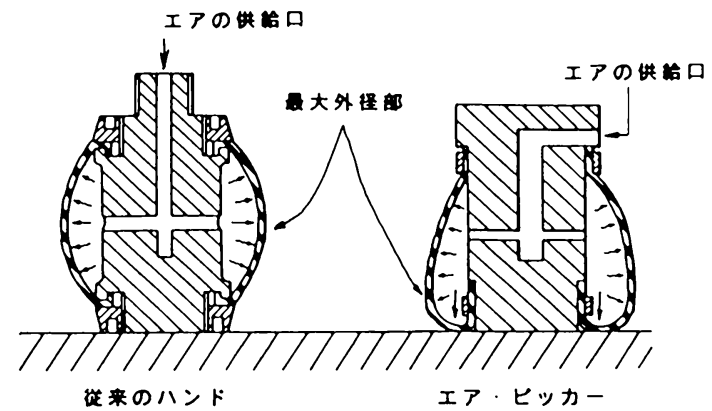

因 3 エフ・ピッカーの特改
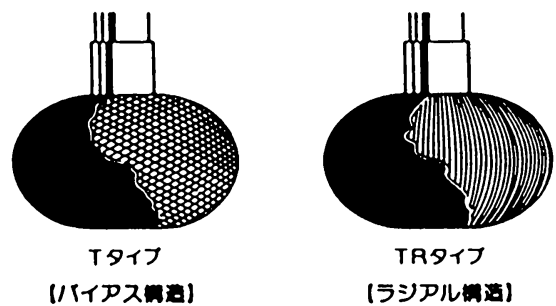

図4コード入りコムタイプのエア・ビッカー

こ，柔らかくて軽いワークに適している。コムの 種類は一般産業用黒コムと食品医療用シリコーン ゴムがある。長期にわたって安定的に膨らませる ためには、ゴム厚みのばらつきを極力抑えること が必要であるが，精密ゴム加工技術の開発により ゴム厚みは汪湆均一になっている。コード入りコ ムタイブは更に高精度の寸法安定性を得るために 開発されたもので，極細(直径 $0.2 \mathrm{~mm}$ )のテキス タイルコードがゴムチューブの内部に高密度で埋 設されている。コードの配列の方向は，図 4 に示 すよらにタイヤと同じくハィイス構造とラジアル 構造がある。両方の構造とも長期にわたり拔群の 寸法安定性を示すが，バイアス構造はラジアル構 造に比べて高い圧力に耐える設計になっているの で重量の重いワークに適している。

\section{2 特性}

多品種小量生産の現場では、ワークに合わせた 機能をもつハンドをその都度用意しなけれはななら ない、また、サイクルタイム短縮による生産性向 上を四るために，ますます小型・軽量のハンドを 必要としている。エア・ビッカーとェア・グリッ ハーは，非常にンンブルな構造であり，しかも空 気圧に応して膨らみが变化する柔軟性をもつので 
生産現場のニーズに充分応えられると考える．眓 5 に外観を，表 1，表 2 に主な仕様を示す。

図 6 は土ア・ビッカー外径と空気圧との関保を 示すグラフである.コード入りゴムタイブは空気 圧を高くすると一定の外径に近づくのに対して， 総ゴムタイプは風船のよらにどんどん膨らむ傾向 がある．総ゴムタイブを使用する場合は，特に空 気圧の管理が大切である。

図７はワーク径をバラメータにした推奖可搬重 量と空気圧との関保を示すグラフである。エア． ピッカーは品番 P035Tを，エア・グリッパーは 品番 $\mathrm{G} 050$ を代表例とした，当然のことながら， エア・ピッカーはワーク内径が小さいほど，また エア・グリッハーーはワーク外径が大きいほど，可 搬重量が大きくなるが，これはワークとゴムチュ 一ブとの接触面積の大きさに関係している。

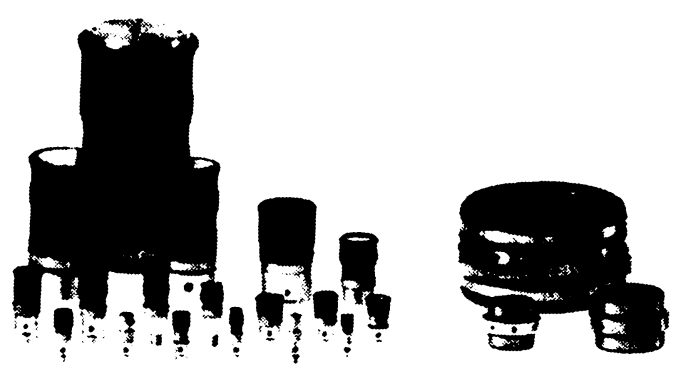

困 5 外睍

耐久性については使用環境条件により大きく異 なるので一概にはいえないが，ひとつの目安とし て示すならワークの表面が滑らか( $\nabla \nabla$ 程度)で, 油・溶郕などの付着物がなく常温であるならば， 約 100万回の寿命がある.

表1エア・ピッカーの主な仕様

\begin{tabular}{|c|c|c|c|c|c|c|c|c|}
\hline $\begin{array}{l}\text { 製 } \\
\text { 品 } \\
\text { 名 }\end{array}$ & $\begin{array}{l}\text { タ } \\
1 . \\
7\end{array}$ & 品 番 & $\begin{array}{c}\text { 適用ワーク内径 } \\
(\mathrm{mm})\end{array}$ & $\begin{array}{c}\text { 推奖可搬重量 } \\
(\mathrm{g})\end{array}$ & $\begin{array}{c}\text { 使用最大空気王 } \\
\left(\mathrm{kg} / \mathrm{cm}^{2}\right)\end{array}$ & 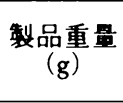 & 桠 造 & ゴム質 \\
\hline \multirow{4}{*}{$\begin{array}{c}x \\
\text { 了 } \\
\text {. } \\
\text { ヒै } \\
\text { \% } \\
\text { カ } \\
1\end{array}$} & $\begin{array}{l}\mathrm{T} \\
\mathrm{R} \\
\text { 夕 } \\
1 \\
7 .\end{array}$ & $\begin{array}{l}\text { P010TR } \\
\text { P014TR } \\
\text { P019TR } \\
\text { P025TR }\end{array}$ & $\begin{array}{l}\phi 16 \sim 21 \\
\phi 20 \sim 27 \\
\phi 26 \sim 39 \\
\phi 32 \sim 54\end{array}$ & $\begin{array}{l}2,000 \\
3,000 \\
4,000 \\
5,000 \\
\end{array}$ & $\begin{array}{l}3.0 \\
5.0 \\
5.0 \\
5.0 \\
\end{array}$ & $\begin{array}{r}30 \\
55 \\
110 \\
240 \\
\end{array}$ & $\begin{array}{l}\text { コード入り } \\
\text { (ラジフル) }\end{array}$ & $\begin{array}{l}\text { 黒ゴム } \\
\text { (ダイブC) }\end{array}$ \\
\hline & $\begin{array}{l}\mathrm{T} \\
\text { 夕 } \\
1 \\
7\end{array}$ & $\begin{array}{l}\text { P025T } \\
\text { P035T } \\
\text { P045T } \\
\text { P055T }\end{array}$ & $\begin{array}{l}\phi 32 \sim 46 \\
\phi 45 \sim 65 \\
\phi 58 \sim 85 \\
\phi 70 \sim 105\end{array}$ & $\begin{array}{r}7,000 \\
10,000 \\
12,000 \\
15,000 \\
\end{array}$ & $\begin{array}{l}5.0 \\
5.0 \\
5.0 \\
5.0 \\
\end{array}$ & $\begin{array}{l}240 \\
175 \\
400 \\
600 \\
\end{array}$ & $\begin{array}{l}\text { コード入り } \\
(\text { ハイフス) }\end{array}$ & (黒ゴム \\
\hline & $\begin{array}{l}G \\
\text { タ } \\
1 \\
7 .\end{array}$ & $\begin{array}{l}\text { P010G } \\
\text { P014G } \\
\text { P019G } \\
\text { P023G }\end{array}$ & $\begin{array}{l}\phi 14 \sim 22 \\
\phi 20 \sim 28 \\
\phi 26 \sim 34 \\
\phi 31 \sim 39\end{array}$ & $\begin{array}{r}350 \\
450 \\
750 \\
1,000 \\
\end{array}$ & $\begin{array}{l}1.4 \\
1.6 \\
1.8 \\
1.8 \\
\end{array}$ & $\begin{array}{r}30 \\
55 \\
100 \\
150 \\
\end{array}$ & 総ゴム & $\begin{array}{l}\text { 黑ゴム } \\
\text { (タ゚イプ R) }\end{array}$ \\
\hline & $\begin{array}{l}\mathrm{G} \\
1 \\
\mathrm{~S} \\
4 \\
1 \\
7\end{array}$ & $\begin{array}{l}\text { P010G-S } \\
\text { P014G-S } \\
\text { P019G-S } \\
\text { P025G-S }\end{array}$ & $\begin{array}{l}\phi 16 \sim 20 \\
\phi 19 \sim 29 \\
\phi 26 \sim 30 \\
\phi 31 \sim 35\end{array}$ & $\begin{array}{l}200 \\
250 \\
400 \\
550\end{array}$ & $\begin{array}{l}0.7 \\
0.7 \\
0.8 \\
0.9\end{array}$ & $\begin{array}{r}30 \\
55 \\
100 \\
240\end{array}$ & 総ゴム & シリコーンコムム \\
\hline
\end{tabular}

表 2 エア・クリリッパーの主な仕様

\begin{tabular}{|c|c|c|c|c|c|c|c|c|}
\hline 製 & $\begin{array}{l}\text { タ } \\
1 \\
7\end{array}$ & 品番 & $\begin{array}{c}\text { 適用ワーク外径 } \\
(\mathrm{mm})\end{array}$ & $\begin{array}{c}\text { 推奖可搬重量 } \\
(\mathrm{g})\end{array}$ & $\begin{array}{c}\text { 使用最大空気圧 } \\
\left(\mathrm{kg} / \mathrm{cm}^{2}\right)\end{array}$ & $\begin{array}{c}\text { 製品重量 } \\
(\mathrm{g})\end{array}$ & ボディ材質 & ゴム質 \\
\hline$\frac{x}{7}$ & \multirow{3}{*}{ - } & G030 & $\phi 10 \sim 25$ & 2,000 & 1.5 & 130 & \multirow{2}{*}{ アルミ } & \multirow{3}{*}{ 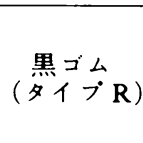 } \\
\hline 焉, & & G040 & $\phi 15 \sim 35$ & 2,500 & 1.5 & 200 & & \\
\hline$\because=$ & & G050 & $\phi 20 \sim 45$ & 3,000 & 1.5 & 480 & ステンレス & \\
\hline
\end{tabular}



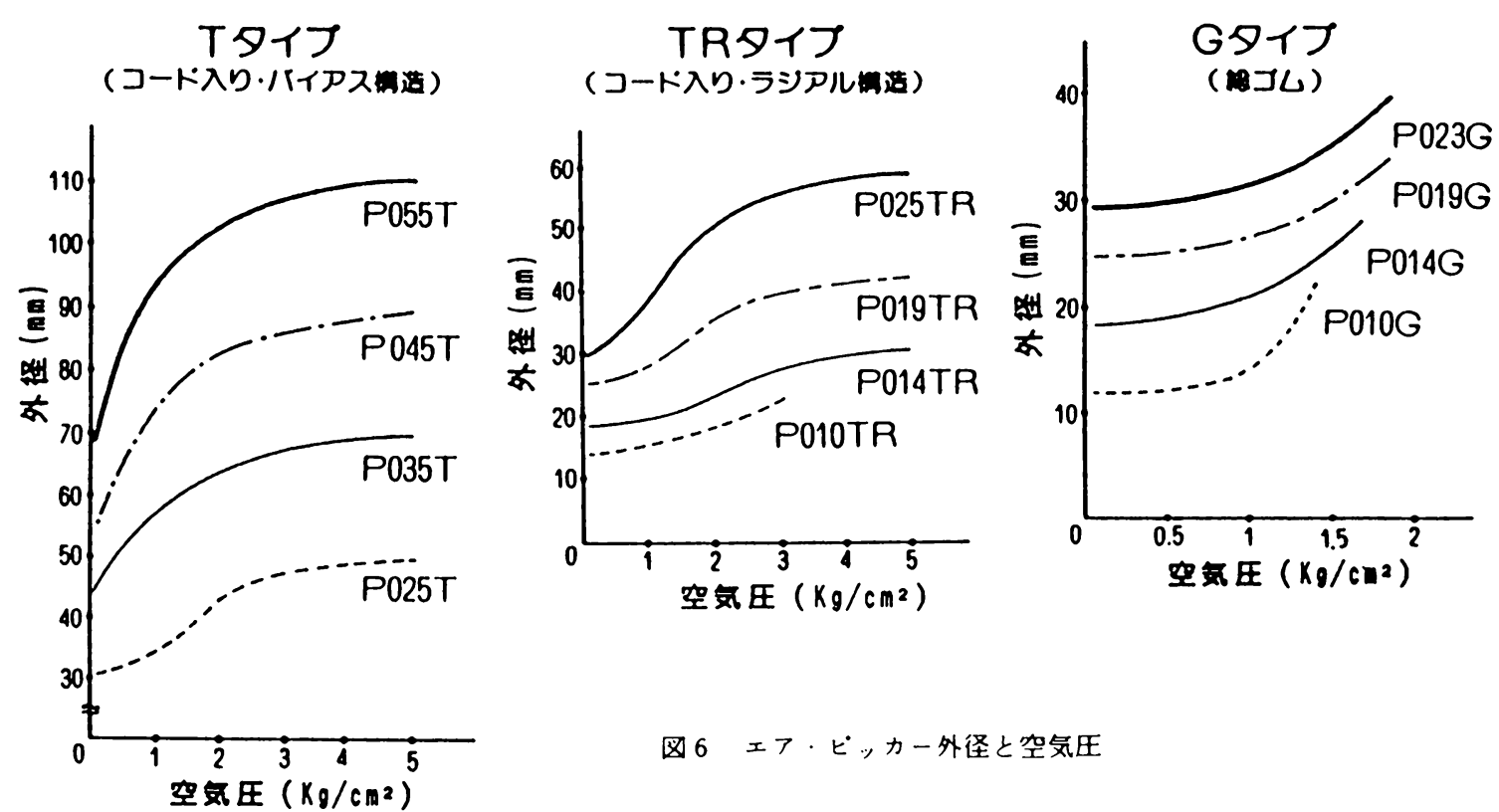

困 6 エフ・ピッカー外径と空気压
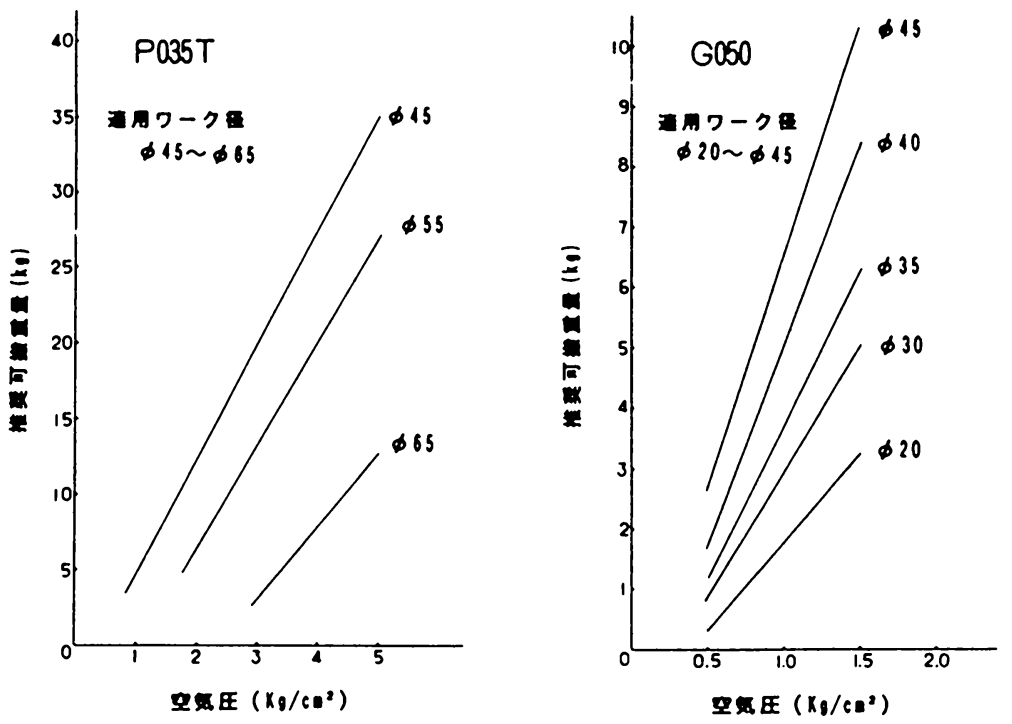

因 7 推奖可掓重量と空気圧

\section{3 特 徽}

エア・ピッカーエエア・グリッハーの特改をま とめると次のとおりである。

(1) ソフトにホールドできる.

從来のハカニカルなチャックがワークと点や線 で接触するのに対して、これらのハンドは厇い
面でホールドするため低圧空気でもしっかりつ かむことができるのでワークを傷つけることは ない.

（2）小型・俥量

多数のワークを一度に取り扱ら（例えば，射出 成形品の取り出し)よらな使用方法にも対応で 
きる、例えば，P019TRの特殊品では1つの

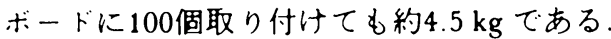

（3）応答性が良い。

瞬時に空気の注入・排出ができるので，高速作 業サイクルにも適応できる。

(4) 適用範囲が厸い。

空気圧に応じて膨らみが変わるので，多品種小 量生産現場における異形ワークにも充分対応て きる。

（5）戦密な七ンターリングが不要である。

(6) ハンドリングが自在である.

ワークの広い面積にわたって均一にホールドす るので、クランブ力が大きく回転など自在な公 ンドリングが可能である。

（7）省エネ効果が大きい.

低い空気圧で使用できるし，空気の消費量も少 ない.

（8）防爆性が高い。

（9）給油が不要である。

機械的な可動部分がないので，無給油でよい。 (10)防歴性が高い.

機械的な可動部分がないので，粉体などによる 日づまりがない。

\section{4 応用例}

エア・ビッカー及びェア・グリッハーは，物を
つかをといら基本的な機能はもちろんのこと， 一ル機能やストッハ機能を持つので、これらの八 ンドが使用される分野は非常に広い。これまでに 検討してきた事例の中から代表的な応用例を，工 ア・ビッカーについては図8，エア・グリッハー については図 9 に紹介する.

\section{3. 新型ニューマチックハンドの關発}

現在，標準品としてェア・ピッカーを16種類， エア・グリッパーを3 種類ラインナップしている が、これらのサイズですべてのューザ・ニーズを 満足しているわけではない，多種多様なユーザ. ウォンツを実現させるため，新しいタイプの二ュ ーマチックハンドを開発中なので，その中からい くつかを次に紹介する。

3.1 桱細エア・ピッカーの開発

軽薄短小のワークが增加しているためか，小穴 でも把持できるエア・ピッカ一の製作依頼が多 い.ところがコード入りコムタイプの最小サイズ はP010TRなので, 内径かi16 $\mathrm{mm}$ 以上のワーク でないと対応できなかった。しかし，製造技術の 改良によりワーク内径が $8.5 \mathrm{~mm}$ 以上であれは把 持できる極細エア・ピッカーを開発した。更に小 型サイズの超極細エア・ピッカーを現在検討中で ある。

\section{1. 朕（内面ホールド）}
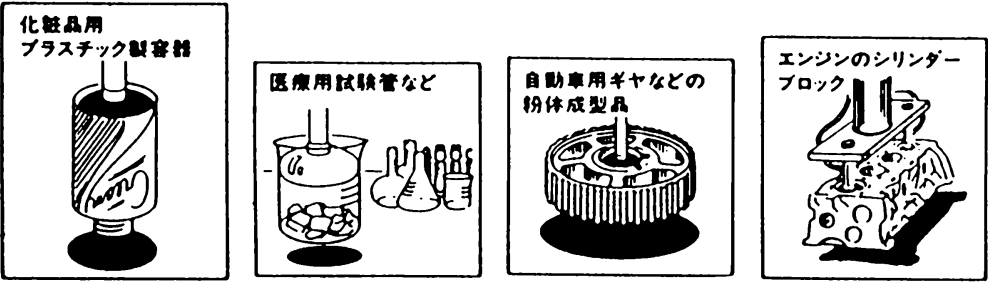

2. 朕（外面ホールド）
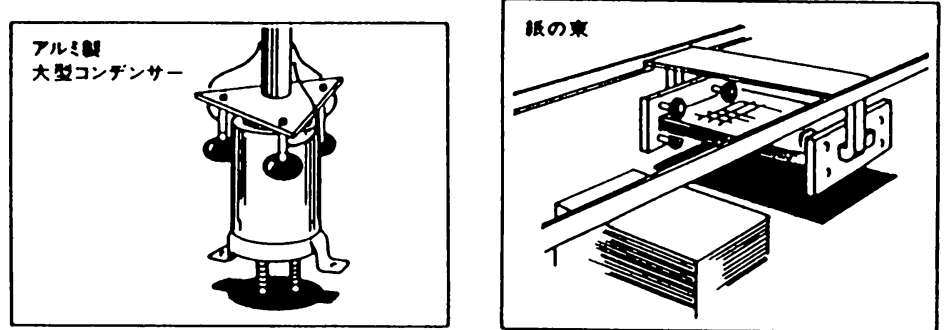

因 8-1エア・ピッカーの応用例(その1) 
3. シール
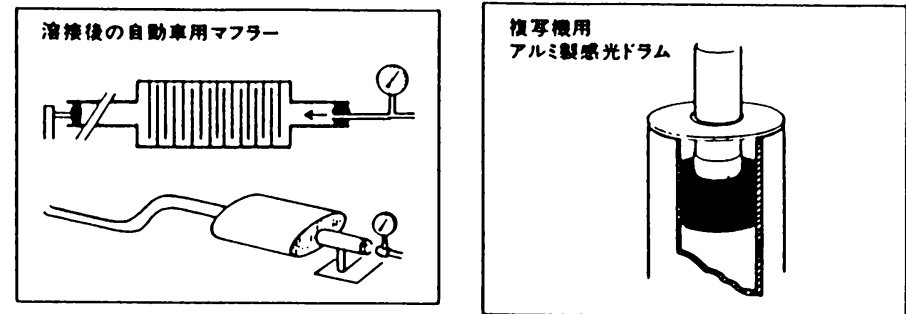

4.ストッパ
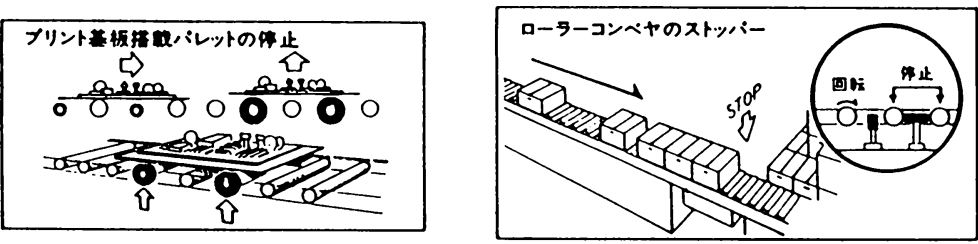

困 8-2 エア・ピッカーの応用例(その 2)

\section{1. 送}
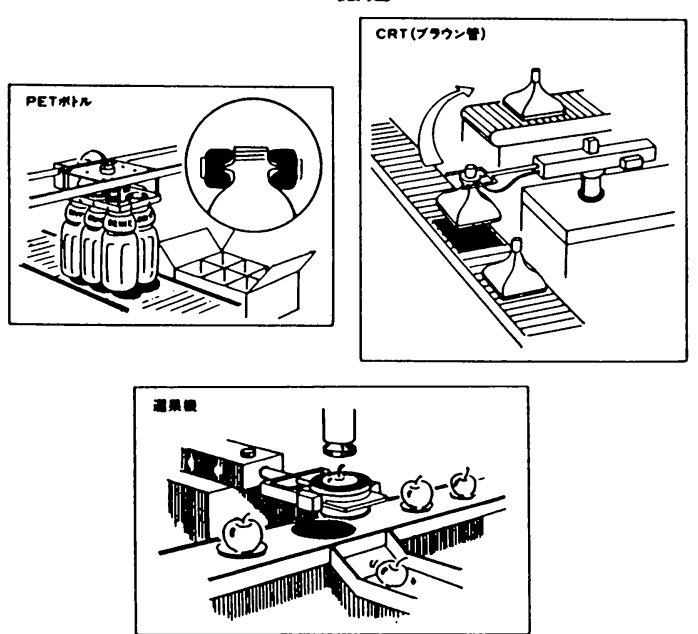

2. シール

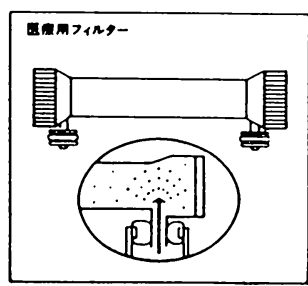

図 9 エア・グリッパーの応用例

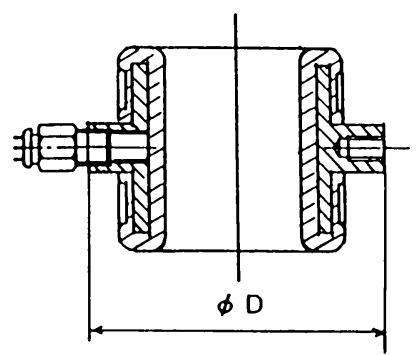

図10-1 エア・グリッハー

\section{2 エア・グリッピーの開発}

エア・グリッパーは応用例として PETボトル の搬送を取り上げたように，一度に多数のワーク を搬送する場合に使用されることが多い。しか し，吸排気口や口ボットとの取付用ねじ穴を中央 フランヂ部に設けるため，図10-1に示すよ5に 製品の最大外径 $(\phi D)$ を小さくすることは構造上 限界があった。このためワーク間のピッチが広け れば使用できるが，ピッチが狭くなるとェア・グ リッパー同士が干涉して使用できないヶースがあ った。そこで，ワーク間のピッチが狭くても充分 対応できるハンドとして，ェア・グリッピー (AIR GRIPPI) を開発した。図10-2に示すよ5 に，吸排気ロやロボットとの取付用ボルトを中心 

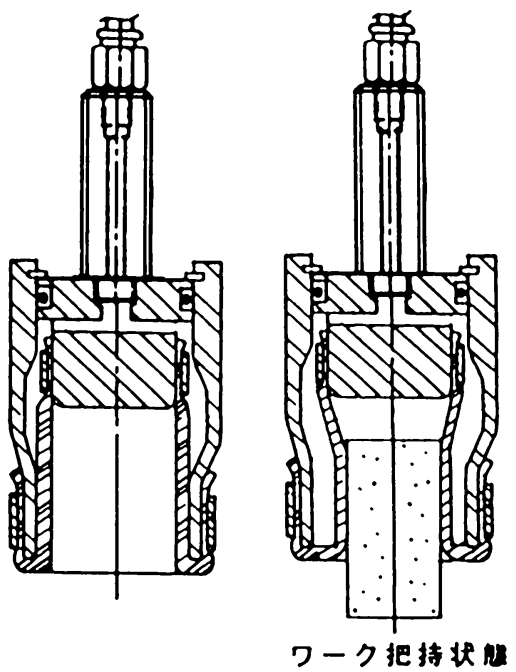

四10-2エア・グリッピー

軸上に設けたので，従来のエア・クリッハーに比 ベてスリムな㩐造である。

\section{3 伸縮及び漓曲型ハントの閏発}

コムチューブの中にハイアス楼造のテキスタイ ルコートを埋設し、コートの角度变化を利用及び 調整することで伸張，又は収樎，又は饬曲する八 ンドである。これはハイアス状のコードが入た コムチューブに内圧を与えたとき，力のつり合い によりコードがある一定の角度（静止角度 $\alpha$ と呼 ぶ)に変化することを利用している。

檴造はコムチューブの両端を加編リングにより ボディに固定したンンブルなものである。図11は 伸張するハントである。コートか乙方向に対し て $\beta$ の角度で入っており， $\beta$ は $\alpha$ より大きくし てある、困12は収縮するハントである。これは迸 に $\beta$ はよりも小さくしてある。图13はコムチ ューフの一側面に動きを規制するコートをZ方 向に更に埋設したもので，ある一定の方向に淬曲 するハンドである。これは人間の指に近い動きを するハンドで，空気压を調整することで指の曲率 半径を间単に変化させることができる。

\section{4 コム材公の閶発}

ごチュープの材質は常温大気中で使用するこ とを前提として，耐候性や耐疲労性に優九る NR/BR系，CR系のコムムを使用している。しか し、これらのゴムは有機溶都や油の中で使用する と、橵潤しゴム弾性を失らといら久点がある。

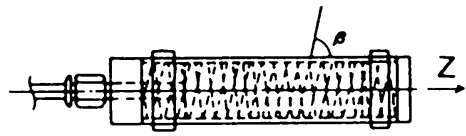

给気前

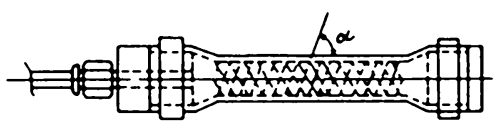

给视啳

困11伸張するハント

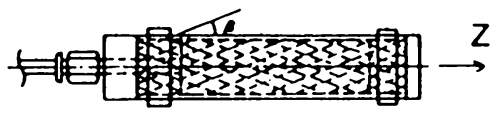

铪氛前

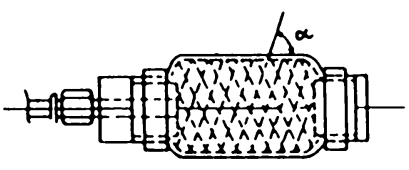

告気倦

困12収縮するハント
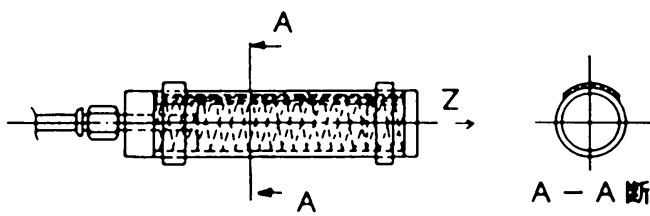

$A-A$ 激面

给気前

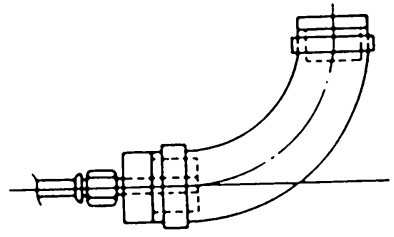

合気信

困13管曲するハント

た高温下で使らとコム物性が低下するおそれもあ る。そこで各種使用懪境に応じて表 3 に示すコム 材質を選択し，エア・ピッカー，エア・クリッハ 一用に配合条件なとを検討している．今のところ はほ使用できる見通しからつい段階である。 


\begin{tabular}{|c|c|c|}
\hline \multicolumn{2}{|c|}{ 使用珢境 } & 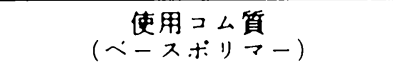 \\
\hline \multirow{2}{*}{ 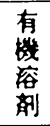 } & 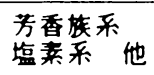 & フッ秦 \\
\hline & ケトン系他 & IIR/EPDM \\
\hline 高 & $150^{\circ} \mathrm{C}$ 以上 & フ,素 \\
\hline \multicolumn{2}{|c|}{ 耐油. 耐䓡 } & ${ }_{\text {水添化 }}^{\text {NBR }}$ \\
\hline \multicolumn{2}{|c|}{ 耐熱，非污染 } & $\begin{array}{c}\text { クロロスルホン化ホリエチレン } \\
\text { (商品名ハイパロ }\end{array}$ \\
\hline
\end{tabular}

\section{4. 結列}

人間の手を見ると実にらまくできている．5本 の指は見事に協調制御し，とんなワークでも平気 でつかんでしまう。我々は人間の手に一步でも半 步でも近つくことができるよ5に，ソフトタッチ な感覚をもつニューマチックハントを開発してい る. 現在のところは，人の手の感覚にあたる機能 むなく，単純な動作しかできないが，柔らかさと いら従来のハカニカルなハントにはない独特の素 質をもった将来性豊かなハンドであると考えてい る、この素質を開花させるため，今後ともより一 層の研究開発を推進したいと思ら。

日本コム協会語特集号バックナンバー

（送料 1 冊 61円）

\begin{tabular}{|c|c|c|c|c|c|c|c|}
\hline 巷 & 号 & 年 & 特 & 基 & 名 & 定価（円） & 会目（円） \\
\hline Vol. 57 & No. 8 & 1984 & ゴムの粘接着 & & & 1,200 & 1,080 \\
\hline Vol. 59 & No. 6 & 1986 & 碚能性エラス & トマー & & 1,200 & 1,080 \\
\hline Vol. 59 & No. 11 & 1986 & 表面処理 & & & 2,500 & 2,250 \\
\hline Vol. 60 & No. 2 & 1987 & 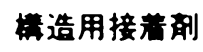 & & & 1,200 & 1,080 \\
\hline Vol. 60 & No. 7 & 1987 & ユーサーとの & 桽談会 & （小特集） & 2,500 & 2,250 \\
\hline Vol. 61 & No. 2 & 1988 & 熱可塑性エラ & ストマ & & 2,500 & 2,250 \\
\hline Vol. 61 & No. 5 & 1988 & 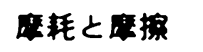 & & & 2,500 & 2,250 \\
\hline Vol. 61 & No. 7 & 1988 & 創立60周年記 & 念特雀 & 一紀索引付 & 1,200 & 1,080 \\
\hline Vol. 61 & No. 9 & 1988 & 望西性材料 & & & 2,500 & 2,250 \\
\hline Vol. 61 & No. 12 & 1988 & 光とエラスト & マー & & 2,500 & 2,250 \\
\hline Vol. 62 & No. 3 & 1989 & ゴム加工技術 & の毁近 & 刀功向 & 2,500 & 2,250 \\
\hline Vol. 62 & No. 6 & 1989 & 生体・医用工 & ラスト & २- & 2,500 & 2,250 \\
\hline
\end{tabular}

協会誌特集号のらち上記バックナンバーの在庫が多少ありますので，御希望の方は本会図書俰あて お申込み下さい，また，普通号は一部欠本がりますか 59 巻より現在61巻までそろっております。 代金は現金書留か郵便振替（東京 9-48393）にてお願いいたします。 ※平成元年 4 月 1 日以降定価のほかに $3 \%$ の消貫䬽が加算されますので御了承下さい. 